\title{
The Brazilian Research Consortium on Obsessive- Compulsive Spectrum Disorders: recruitment, assessment instruments, methods for the development of multicenter collaborative studies and preliminary results Consórcio Brasilleiro de Pesquisa em Transtornos do Espectro Obsessivo-Compulsivo: recrutamento, instrumentos de avaliação, métodos para o desenvolvimento de estudos colaborativos multicêntricos e resultados preliminares
}

Euripedes Constantino Miguel, ${ }^{1}$ Ygor Arzeno Ferrão, ${ }^{2}$ Maria Conceição do Rosário, ${ }^{3,4}$ Maria Alice de Mathis, ${ }^{1}$ Albina Rodrigues Torres, ${ }^{5}$ Leonardo Franklin Fontenelle, ${ }^{6}$ Ana Gabriela Hounie, ${ }^{1}$ Roseli Gedanke Shavitt, ${ }^{1}$ Aristides Volpato Cordioli, ${ }^{7}$ Christina Hojaij Gonzalez, ${ }^{3}$ Kátia Petribú, ${ }^{8}$ Juliana Belo Diniz, ${ }^{1}$ Dante Marino Malavazzi, ${ }^{1}$ Ricardo C Torresan, ${ }^{5}$ Andréa Litvin Raffin, ${ }^{7}$ Elisabeth Meyer, ${ }^{7}$ Daniela T Braga, ${ }^{7}$ Sonia Borcato, ${ }^{1}$ Carolina Valério, ${ }^{1}$ Luciana N Gropo, ${ }^{8}$ Helena da Silva Prado, ${ }^{3}$ Eduardo Alliende Perin, ${ }^{3}$ Sandro lêgo Santos, ${ }^{4}$ Helen Copque,, Manuela Corrêa Borges, ${ }^{6}$ Angélica Prazeres Lopes, ${ }^{6}$ Elenita D da Silva, ${ }^{8}$ The Brazilian Research Consortium on Obsessive-Compulsive Spectrum Disorders (CTOC)*

Abstract

Objective: To describe the recruitment of patients, assessment instruments, implementation, methods and preliminary results of The Brazilian Research Consortium on Obsessive-Compulsive Spectrum Disorders, which includes seven university sites. Method: This crosssectional study included a comprehensive clinical assessment including semi-structured interviews (sociodemographic data, medical and psychiatric history, disease course and comorbid psychiatric diagnoses), and instruments to assess obsessive-compulsive (Yale-Brown Obsessive-Compulsive Scale and Dimensional Yale-Brown Obsessive-Compulsive Scale), depressive (Beck Depression Inventory) and anxious (Beck Anxiety Inventory) symptoms, sensory phenomena (Universidade de São Paulo Sensory Phenomena Scale), insight (Brown Assessment Beliefs Scale), tics (Yale Global Tics Severity Scale) and quality of life (Medical Outcome Quality of Life Scale Short-form-36 and Social Assessment Scale). The raters' training consisted of watching at least five videotaped interviews and interviewing five patients with an expert researcher before interviewing patients alone. The reliability between all leaders for the most important instruments (Structured Clinical Interview for DSM-IV, Dimensional Yale-Brown Obsessive-Compulsive Scale, Universidade de São Paulo Sensory Phenomena Scale) was measured after six complete interviews. Results: Inter-rater reliability was 96\%. By March 2008, 630 obsessive-compulsive disorder patients had been systematically evaluated. Mean age ( \pm SE) was $34.7( \pm 0.51), 56.3 \%$ were female, and $84.6 \%$ Caucasian. The most prevalent obsessive compulsive symptom dimensions were symmetry and contamination. The most common comorbidities were major depression, generalized anxiety and social anxiety disorder. The most common DSM-IV impulsive control disorder was skin picking. Conclusion: The sample was composed mainly by Caucasian individuals, unmarried, with some kind of occupational activity, mean age of 35 years, onset of obsessive-compulsive symptoms at 13 years of age, mild to moderate severity, mostly of symmetry, contamination/ cleaning and comorbidity with depressive disorders. The Brazilian Research Consortium on Obsessive-Compulsive Spectrum Disorders has established an important network for standardized collaborative clinical research in obsessive-compulsive disorder and may pave the way to similar projects aimed at integrating other research groups in Brazil and throughout the world.

Descriptors: Obsessive-compulsive disorder; Clinical medicine; Multicenter study; Diagnosis; Prevalence 


\section{Resumo}

Objetivo: Descrever o recrutamento de pacientes, instrumentos de avaliação, métodos para o desenvolvimento de estudos colaborativos multicêntricos e os resultados preliminares do Consórcio Brasileiro de Pesquisa em Transtornos do Espectro Obsessivo-Compulsivo, que inclui sete centros universitários. Método: Este estudo transversal incluiu entrevistas semi-estruturadas (dados sociodemográficos, histórico médico e psiquiátrico, curso da doença e diagnósticos psiquiátricos comórbidos) e instrumentos que avaliam os sintomas do transtorno obsessivo-compulsivo (Escala para Sintomas Obsessivo-Compulsivos de Yale-Brown e Escala Dimensional para Sintomas Obsessivo-Compulsivos de Yale-Brown), sintomas depressivos (Inventário de Depressão de Beck), sintomas ansiosos (Inventário de Ansiedade de Beck), fenômenos sensoriais (Escala de Fenômenos Sensoriais da Universidade de São Paulo), juízo crítico (Escala de Avaliação de Crenças de Brown), tiques (Escala de Gravidade Global de Tiques de Yale) e qualidade de vida (questionário genérico de avaliação de qualidade de vida, Medical Outcome Quality of Life Scale Short-form-36 e Escala de Avaliação Social). O treinamento dos avaliadores consistiu em assistir cinco entrevistas filmadas e entrevistar cinco pacientes junto com um pesquisador mais experiente, antes de entrevistar pacientes sozinhos. A confiabilidade entre todos os líderes de grupo para os instrumentos mais importantes (Structured Clinical Interview for DSM-IV, Dimensional Yale-Brown Obsessive-Compulsive Scale, Universidade de São Paulo Sensory Phenomena Scale ) foi medida após seis entrevistas completas. Resultados: A confiabilidade entre avaliadores foi de $96 \%$. Até março de 2008,630 pacientes com transtorno obsessivo-compulsivo tinham sido sistematicamente avaliados. A média de idade ( \pm SE) foi de 34,7 ( $\pm 0,51)$, $56,3 \%$ eram do sexo feminino e $84,6 \%$ caucasianos. Os sintomas obsessivo-compulsivos mais prevalentes foram os de simetria e os de contaminação. As comorbidades psiquiátricas mais comuns foram depressão maior, ansiedade generalizada e transtorno de ansiedade social. O transtorno de controle de impulsos mais comum foi escoriação neurótica. Conclusão: Este consórcio de pesquisa, pioneiro no Brasil, permitiu delinear o perfil sociodemográfico, clínico e terapêutico do paciente com transtorno obsessivo-compulsivo em uma grande amostra clínica de pacientes. O Consórcio Brasileiro de Pesquisa em Transtornos do Espectro Obsessivo-Compulsivo estabeleceu uma importante rede de colaboração de investigação clínica padronizada sobre o transtorno obsessivo-compulsivo e pode abrir o caminho para projetos semelhantes destinados a integrar outros grupos de pesquisa no Brasil e em todo o mundo.

Descritores: Transtorno obsessivo-compulsivo; Medicina clínica; Estudo multicêntrico; Diagnóstico; Prevalência

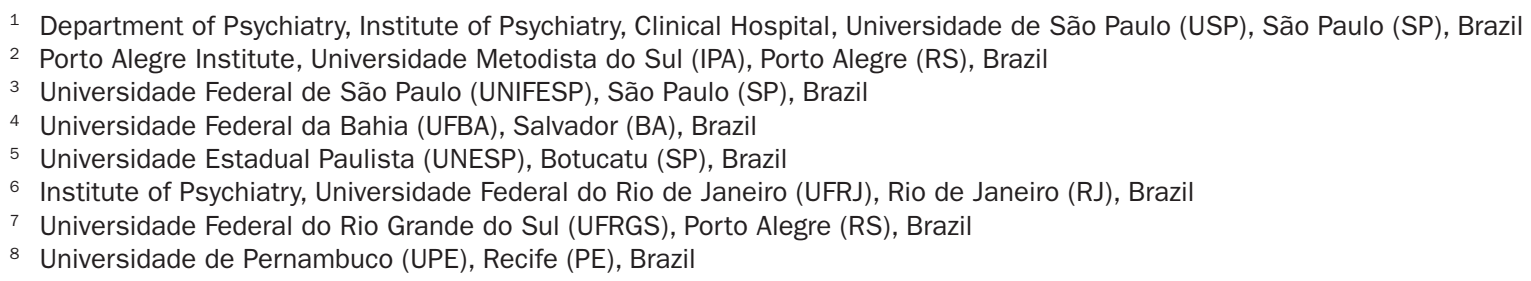

\section{* CTOC members:}

USP - Leader: Euripedes C. Miguel. Members: Aline S Sampaio, Ana G Hounie, André A Seixas, André Gentil, Anita Taub, Antonio C Lopes, Ariane Machado Lima, Carina C. D’Alcante, Carolina Cappi, Carolina Valério, Cristina Belotto da Silva, Dante Marino Malavazzi, Isabel Pimentel, Ivanil Morais, Juliana B. Diniz, Marcelo Batistuzzo, Marcelo Hoexter, Maria Alice de Mathis, Maria Eugênia De Mathis, Marinês A. Joaquim, Pedro Alvarenga, Priscila Chacon, Quirino Cordeiro, Roseli G Shavitt, Sonia Borcatto. Statistics: Carlos Alberto de Bragança Pereira, Victor Fossaluza. UNIFESP - Leaders: Maria Conceição do Rosário and Christina H. Gonzales. Members: Armando Rezende, Eduardo Alliende Perin, Helena Prado, Patrícia Veloso, Rosana Savio Mastrorosa, Tatiane Cristina Ribeiro. UNESP - Leader: Albina Rodrigues Torres. Members: Ana Teresa A. Ramos-Cerqueira, Érica Vasques Trench, Melissa Chagas Assunção, Ricardo Cezar Torresan. UFRJ - Leader: Leonardo F. Fontenelle. Members:Angélica P. Lopes, Manuela C. Borges. UFBA - Leader: Maria Conceição do Rosário. Members: Amanda Galvão de Almeida, Helen Copque, Samantha Nunes Santos, Sandro lego. UPE - Leader: Kátia Petribú. Members: Anna Guerra Toniolo, Cristiana Machado, Daisy Pontual, Elenita Domingues, Ilduara Sidrim, Juliana Oliveira, Luciana Gropo, Luis Evandro Lima Filho, Moacir Pires, Priscylla Jennie Rabelo. UFRGS-IPA - Leaders: Aristides Volpato Cordioli and Ygor Arzeno Ferrão. Members: Andréa L. Raffin, Daniela Braga, Elisabeth Meyer da Silva, Fernanda Pasquotto de Souza, Helena Bins, Kátia Niederauer, Lucas Lovato, Marcelo Basso.

\author{
Correspondence \\ Ygor Arzeno Ferrão \\ Porto Alegre Institute, South Methodist University \\ Rua Padre Chagas, 185/403 \\ Phone: (+55 51)-3346-1077 \\ 90570-080 Porto Alegre, RS, Brazil \\ E-mail: ygoraf@terra.com.br
}




\section{Introduction}

Obsessive-compulsive disorder (OCD) is a common and disabling disorder. ${ }^{1}$ Despite the increasing number of studies investigating aspects of OCD clinical characteristics, genetics, neuroimaging and treatment response, the pathogenesis of the disorder remains unknown, and a substantial number of patients do not respond to available treatments. ${ }^{2,3}$

One of the most frequent constraints that limit the progress of OCD research is the relatively small number of patients enrolled in most studies, which contributes to reducing the statistical power and to limiting interpretation of findings.

Therefore, patient recruitment and proper evaluation is a fundamental step for the development of clinical research. However, this is not always an easy task. There are patients who do not accept participating or do not look for treatment for reasons related to intrinsic characteristics of the condition. These include features such as fear, embarrassment, lack of insight, symptom severity and specific presentations of obsessive-compulsive symptoms (OCS). All of them implicate in more limited access to patients.

Another challenge is to perform a comprehensive evaluation in a great number of patients. Detailed phenotypic interviews are very timeconsuming and need careful training of several reliable interviewers to be administered to a substantial number of subjects.

One strategy to overcome these limitations and optimize recruitment and training efforts is multicenter collaborations between research groups, also called consortiums. This type of initiative, usually limited to a specific research area, has already been applied to several psychiatric disorders, including schizophrenia ${ }^{4}$ and bipolar disorders. ${ }^{5}$ There are no published studies using this type of approach in OCD.
The purpose of this study is to present initial findings of The Brazilian Research Consortium on Obsessive-Compulsive Spectrum Disorders (CTOC), an enterprise of seven Brazilian centers aiming to investigate characteristics of OCD patients and their families, spanning over all areas of OCD research.

More precisely, this paper provides a detailed description of the CTOC implementation and its methodology, including recruitment of patients, assessment instruments, quality assurance procedures and the inter-rater reliability process. We also present the demographic and clinical characteristics of the initial 630 patients evaluated.

\section{Method}

\section{Ethical issues}

CTOC research projects were submitted to and approved by the local Ethics Committees of the involved centers (Process: USP-968/05; IPA-6600023; UFRGS-06/171; Unifesp-302/2006 and UFRJ-0024.0.249.000-06). Written informed consents were obtained from all participants, after a thorough description of the objectives and methods of each study, and the reassurance that their decision to participate or not would not have any impact on their treatment availability. When the subject was younger than 18 years old, a written informed consent form was signed by the subject and also by a parent or legal guardian.

\section{CTOC organization and structure}

The CTOC was created in 2003. It has a self-governing organizational structure to facilitate the establishment of group policies and procedures. There are sub-committees for different issues, as shown in Figure 1.

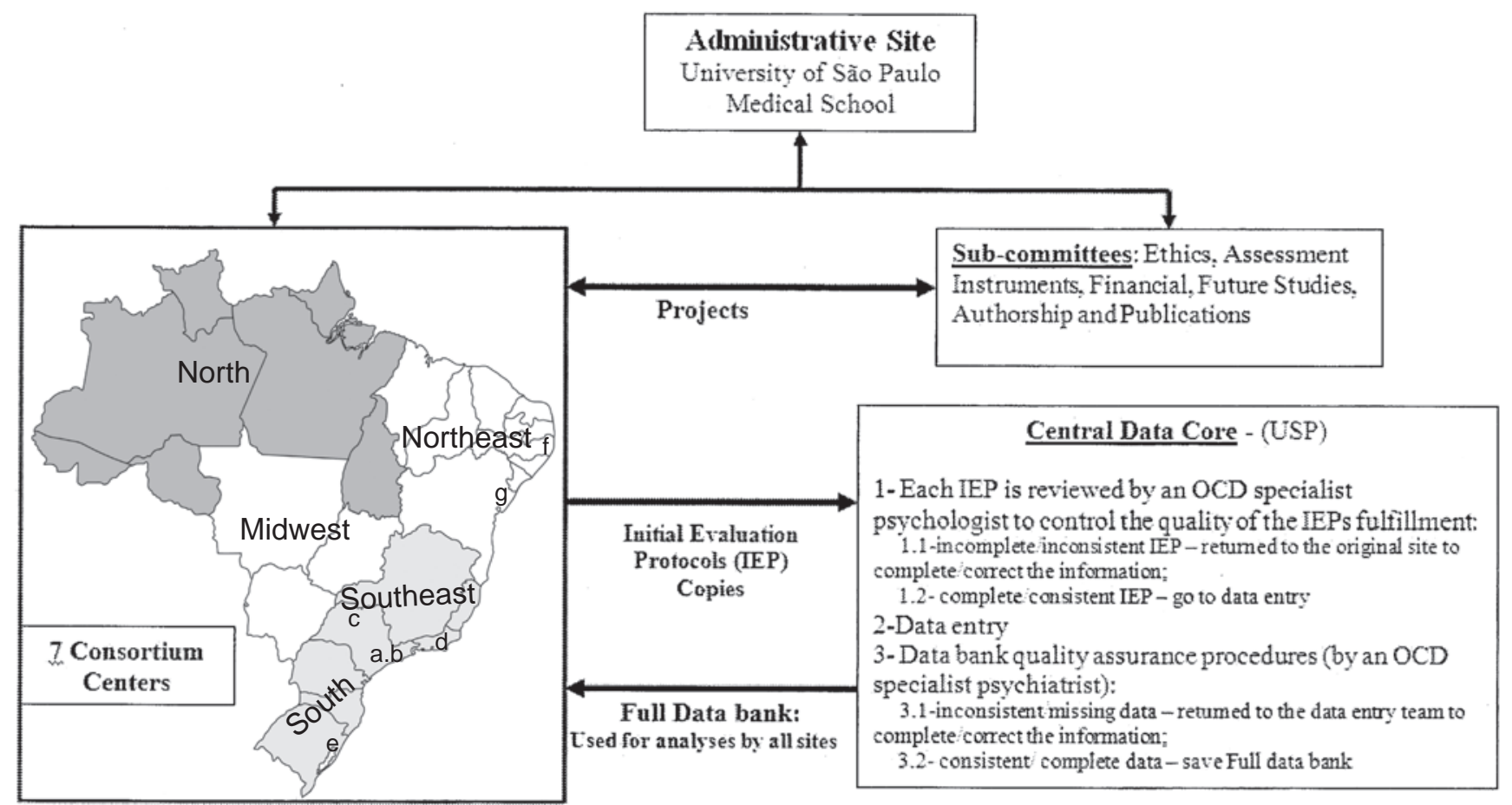

a) Universidade de São Paulo (USP); b) Universidade Federal de São Paulo (Unifesp); c) Universidade Estadual Paulista (Unesp); d) Universidade Federal do Rio de Janeiro (UFRJ); e) Universidade Federal do Rio Grande do Sul and Universidade Metodista do Sul - Instituto Porto Alegre (UFRGS-IPA); f) Universidade Federal de Pernanbuco (UFPE); g) Universidade Federal da Bahia (UFBA). OCD - Transtorno Obsessivo-Compulsivo 
The main objectives of the CTOC are to systematically collect clinical data of OCD patients from multiple centers, building a database for collaborative studies; to stimulate the development of expert groups in this field throughout the country; to share information and to set up a higher standard of care for Brazilian OCD patients; to promote research training in this field; to create, translate, adapt and validate instruments to assess OCD; and to generate new findings that can contribute to the understanding and treatment of OCD and the most common psychiatric comorbidities.

Since 2006, the CTOC has been sponsored mainly by the National Council for Scientific and Technological Development (CNPq, i.e., the Millennium Project), but also by grants from Fundação de Amparo à Pesquisa do Estado de São Paulo (Fapesp).

A website was created to facilitate the communication between members (http://protoc.incubadora.fapesp.br/portal/ctoc/). At this restricted website, assessment instruments, videos for interview training and inter-rater reliability assessment, tasks, workshop planning and other information are available online.

\section{Description of each center}

Brazil is a country with continental dimensions and great cultural diversity. It has 26 states, divided into five regions, and a current population of almost 190 million inhabitants (Brazilian Institute of Geography and Statistics - IBGE, 2008, available at http//:www. ibge.org.br). Each region has its own culture, ethnic distribution, and socioeconomic characteristics. In order to contemplate this diversity, the CTOC is composed of seven centers from five Brazilian states and three different regions (Table 1).

This cross-sectional study is the result of the recruitment of the first three years (from 2005 to 2007). CTOC structure and principles allow each center to have independent research projects in different fields, such as the phenotype dissection of OCD heterogeneity, genetics, neuropsychology, neuroimaging and clinical trials with pharmacotherapy, cognitive-behavioral therapy and neurosurgery for refractory cases. Each leading team may invite researchers from other centers to participate as co-authors, so that several projects are currently underway.

\section{Implementation of the CTOC}

The analyses of the variables originated from the instruments listed bellow will be planned for each new research project, according to the specific characteristics and objectives of the various studies to be conducted with this database. All future studies using the CTOC dataset will be based on predefined hypotheses.

1) Assessment instruments

Initially, the leaders from each center gathered in two different occasions to decide which instruments should be included in the "Initial Evaluation Protocol" and to nominate researchers for each of the sub-committees. The current version of the "Initial Evaluation Protocol" is an assessment package (available at http://protoc. incubadora.fapesp.br/portal/ctoc/) that includes an informed consent form, sociodemographic, socioeconomic (according to Associação Brasileira de Institutos de Pesquisa de Mercado - ABIPEME - scale), medical history data, a semi-structured interview about family psychiatric history (available under request), and the instruments briefly described below. The research protocol is usually completed over the course of one to three meetings (2 to 3 hours each), which are scheduled with intervals as short as possible. Each center may add instruments to this basic research protocol, according to approved specific projects.

2) Clinical assessment

Structured Clinical Interview for DSM-IV (SCID-I) ${ }^{6}$ and additional modules for tic and impulse control disorders. ${ }^{7}$ Attention deficit hyperactivity disorder (ADHD) and separation anxiety disorder are investigated through a module of the Kiddie Schedule for Affective Disorders and Schizophrenia (K-SADS). ${ }^{8}$

Table 1 - Description of The Brazilian Research Consortium on Obsessive-Compulsive Spectrum Disorders (CTOC) centers

\begin{tabular}{|c|c|c|c|}
\hline Region & Site & Characteristics & Team \\
\hline \multirow[t]{4}{*}{ Southeast } & $\begin{array}{l}\text { Universidade de São } \\
\text { Paulo (USP) }\end{array}$ & $\begin{array}{l}\text { The Obsessive-Compulsive Spectrum Disorders Program (PROTOC) is located } \\
\text { in the Institute of Psychiatry, Clinical Hospital, Universidade de São Paulo } \\
\text { Medical School. It is an outpatient and inpatient clinic, serving both children and } \\
\text { adults. }\end{array}$ & $\begin{array}{l}11 \text { psychiatrists, } 12 \text { psychologists, } 3 \\
\text { psychology students, } 2 \text { nurses, } 2 \\
\text { statisticians and } 1 \text { biologist }\end{array}$ \\
\hline & $\begin{array}{l}\text { Universidade Federal } \\
\text { de São Paulo } \\
\text { (UNIFESP) }\end{array}$ & $\begin{array}{l}\text { The Obsessive-Compulsive Disorders Program (PRODOC) and the Child and } \\
\text { Adolescent Psychiatry Unit (UPIA) are located in the teaching hospital of the } \\
\text { Universidade Federal de São Paulo Medical School. It is an outpatient clinic, } \\
\text { serving both children and adults. }\end{array}$ & $\begin{array}{l}3 \text { psychiatrists, } 5 \text { psychologists, } 2 \\
\text { neuropsychologists, } 5 \text { psychiatry } \\
\text { residents and } 2 \text { psychology students }\end{array}$ \\
\hline & $\begin{array}{l}\text { Universidade Estadual } \\
\text { de São Paulo (UNESP) }\end{array}$ & $\begin{array}{l}\text { The Ambulatório de Transtornos Ansiosos e Obsessivo-Compulsivos (ATAOC) of } \\
\text { the public University Hospital of Botucatu Medical School is located in a city } 230 \\
\mathrm{~km} \text { far from the State capital. The city has a hospital that serves patients referred } \\
\text { by health professionals of the surrounding cities. The professional team serves } \\
\text { only adult outpatients. }\end{array}$ & $\begin{array}{l}4 \text { psychiatrists, } 3 \text { psychiatry } \\
\text { residents and } 1 \text { psychologist }\end{array}$ \\
\hline & $\begin{array}{l}\text { Universidade Federal } \\
\text { do Rio de Janeiro } \\
\text { (UFRJ) }\end{array}$ & $\begin{array}{l}\text { This center is located within the Anxiety and Depression Research Program of } \\
\text { the Institute of Psychiatry of the UFRJ (IPUB). A team specifically dedicated to } \\
\text { the CCTOC project was formed. This project was implemented within an } \\
\text { outpatient clinic, serving predominantly adults. }\end{array}$ & 1 psychiatrist and 2 psychologists \\
\hline South & $\begin{array}{l}\text { Universidade Federal } \\
\text { do Rio Grande do Sul } \\
\text { (UFRGS) and Porto } \\
\text { Alegre Institute of the } \\
\text { Universidade } \\
\text { Metodista do Sul (IPA) }\end{array}$ & $\begin{array}{l}\text { This center is located in an outpatient clinic of the teaching hospital of UFRGS, in } \\
\text { Porto Alegre, and has a well-established research team from the two institutions. } \\
\text { The group has been conducting studies on OCD, especially on Cognitive } \\
\text { Behavior Group Therapy, in close collaboration with national and international } \\
\text { researchers. }\end{array}$ & $\begin{array}{l}4 \text { psychiatrists, } 6 \text { psychologists, } 3 \\
\text { undergraduate psychologists and } 1 \\
\text { occupational therapist }\end{array}$ \\
\hline \multirow[t]{2}{*}{ Northeast } & $\begin{array}{l}\text { Universidade de } \\
\text { Pernambuco (UPE) }\end{array}$ & $\begin{array}{l}\text { The CTOC-PE is located within the Osvaldo Cruz University Hospital of UPE, in } \\
\text { Recife. This project was implemented within an outpatient clinic, serving both } \\
\text { adolescents and adults. }\end{array}$ & $\begin{array}{l}3 \text { psychiatrists, } 5 \text { psychologists, } 2 \\
\text { psychiatry residents and } 4 \text { medical } \\
\text { students }\end{array}$ \\
\hline & $\begin{array}{l}\text { Universidade Federal } \\
\text { da Bahia (UFBA) }\end{array}$ & $\begin{array}{l}\text { The Obsessive-Compulsive Service (SERTOC) is located in the teaching hospital } \\
\text { of the Universidade Federal da Bahia (UFBA), in the city of Salvador. It is an } \\
\text { outpatient clinic, serving both children and adults. }\end{array}$ & $\begin{array}{l}3 \text { psychiatrists, } 3 \text { psychologists, } 4 \\
\text { psychiatry residents and } 4 \\
\text { psychology students }\end{array}$ \\
\hline
\end{tabular}


Yale-Brown Obsessive-Compulsive Scale (Y-BOCS). ${ }^{9}$ This scale has been used worldwide to evaluate OCS severity. It has been translated into Portuguese by Asbhar et al., 2002.

Dimensional Yale-Brown Obsessive-Compulsive Scale (DYBOCS). ${ }^{10}$ It evaluates OCS according to specific dimensions, which include obsessions and related compulsions. The severity of each dimension can be independently quantified. Another advantage of this scale is that avoidant behaviors, mental and repetitive rituals are investigated within each dimension, allowing for a more precise evaluation of the severity of patients' symptoms. It also investigates the time spent with OCS, the level of anxiety and interference, with scores ranging from 0 to 5 (maximum of 15 for each dimension). The negative impact of OCS is also measured (maximum score of 30) and the therapeutic response can be evaluated according to specific dimensions. This instrument was simultaneously validated in Portuguese and English.

Yale OCD Natural History Questionnaire (Leckman et al., 2002, unpublished manuscript, translated into Portuguese by Rosário et al., 2002). This is a detailed instrument about OCS onset and course, including several life events and situations that may contribute to trigger, worsen or improve symptoms.

Yale Global Tic Severity Scale (YGTSS). ${ }^{11}$ This scale has been used worldwide to evaluate the nature and severity of motor and vocal tics. Translated into Portuguese by Miguel et al., 2000.

Beck Depression and Anxiety Inventories. ${ }^{12,13}$ Translated into Portuguese by Gorenstein and Andrade, 1996. ${ }^{14}$ These are widely known scales to evaluate depressive and anxiety symptoms.

Universidade de São Paulo Sensory Phenomena Scale (USP-SPS). ${ }^{15}$ The USP-SPS evaluates the presence and severity of sensory phenomena (SP - subjective experiences of physical or mental sensations associated with repetitive behaviors). It is a semistructured scale composed by two parts. The first one investigates the occurrence of past and current SP, divided into physical and mental sensations (examples of each type are supplied), including age at onset. The second part measures the frequency, distress and interference caused by each SP, in Likert scales ranging from 0 to 4 or 5 .

Multimodality Treatment Assessment Study - Swanson, Nolan and Pelham Questionnaire (SNAP - IV) for parents and teachers (translated into Portuguese by Mattos et al., 2006). ${ }^{16}$ This scale evaluates symptoms of hyperactivity and attention deficit.

Brown Assessment of Beliefs Scale (BABS). ${ }^{17}$ Translated into Portuguese by Ferrão and Hounie, 2002. The BABS is a clinicianadministered scale to evaluate different aspects of the patient's insight: conviction regarding the belief, perception of others' views and explanation of different views about it, fixity of belief, attempts to disprove it, whether the individual recognizes a psychiatric/psychological cause for the belief, and presence of ideas of reference.

Social Assessment Scale (SAS). Translated into Portuguese by Gorenstein et al., 2002. ${ }^{18}$ This 42-item scale evaluates the quality of nine areas of participants' social life: work (three areas), leisure, family, marital status, offspring, domestic life and financial status.

Brazilian version of the Medical Outcomes Study Short Form 36 (SF-36). Translated and validated to Portuguese by Ciconelli et al., 1999. ${ }^{19}$ The SF-36 evaluates the quality of life in the previous month and consists of 11 items, subdivided into 36 questions. It comprises questions about physical, social and emotional health, regarding different activities and general limitation.

Clinical Global Impressions Scale (CGI, adapted version). ${ }^{20}$ The CGI investigates the health professional's impression regarding the patient's problem severity.

\section{Training of the Interviewers and CTOC meetings}

In order to guarantee a standardized use of the instruments, experienced clinicians trained the personnel from all the centers. A PhD level psychologist from Universidade de São Paulo (USP) visited the other CTOC sites to conduct training sessions on the application of structured interviews, which had already been used at USP. In addition, since 2003, two-day meetings have been held three times a year to discuss, practice and standardize the utilization of the research instruments (13 meetings so far).

Workshops on specific issues were also organized in order to present research results, discuss new research projects and specific methodological aspects. Brazilian experts on several areas (e.g. immunology, genetics, neuroimaging, neuropsychology, psychopathology of other disorders, statistics, database, etc.) have been invited to improve the discussions.

During every CTOC meeting, a videotaped interview with a patient, including the SCID-I, DY-BOCS and USP-SPS interviews, was watched by all participants, who rated their evaluations using individual answer sheets that were inserted in a specific database for reliability evaluations. Nine meetings with this aim have already been organized so far. As this is an ongoing consortium project, live and videotaped interviews will be continuously rated by participants for reliability purposes (at least twice a year).

Interviews using the above cited instruments, conducted by experienced professionals, are also available at the CTOC website, facilitating new members' training. Training consists of watching at least five videotaped interviews, observing five live interviews and interviewing five patients with the supervision of another researcher before interviewing patients alone. Instructions about the use of the most important instruments are also available at the CTOC website, as well as the most frequent doubts and questions regarding the use of these scales. In case of remaining questions about interviews, the Assessment Instruments sub-committee can be consulted.

The leaders also promote continuous training in their centers to guarantee a high level of reliability among the participants of the local research teams.

All research protocols are sent to the Central Data Core (USP) and are thoroughly reviewed for quality assurance before insertion in the CTOC database. This is performed by a psychologist (MAM) who has directly participated in the training of members from all centers. She extensively checks all the files to detect possible missing or incongruent data. When found, the protocol is returned to the original site for correction (if necessary, the patient is reinterviewed). After insertion, the data are also reviewed by the Database subcommittee, constituted by six members. Copies of the research protocols are stored locally at each center. The final database is available for each center leader (Figure 1).

\section{Types of studies}

1) Phenotypical studies

These are the core projects conducted by the CTOC, since all centers use the "Initial Evaluation Protocol" that has all the phenotypic information. Based on the clinical assessment instruments, several studies on the phenotypical expression of OCD are being conducted or being prepared, including gender differences, early vs. late onset of symptoms, specific comorbidity patterns (e.g. patients with and without tic disorders, substance use and impulse control disorders, and social anxiety disorder) and specific clinical features of some symptom dimensions (e.g. hoarding obsessions and compulsions), presence of suicidal thoughts, plans and attempts, etc. 


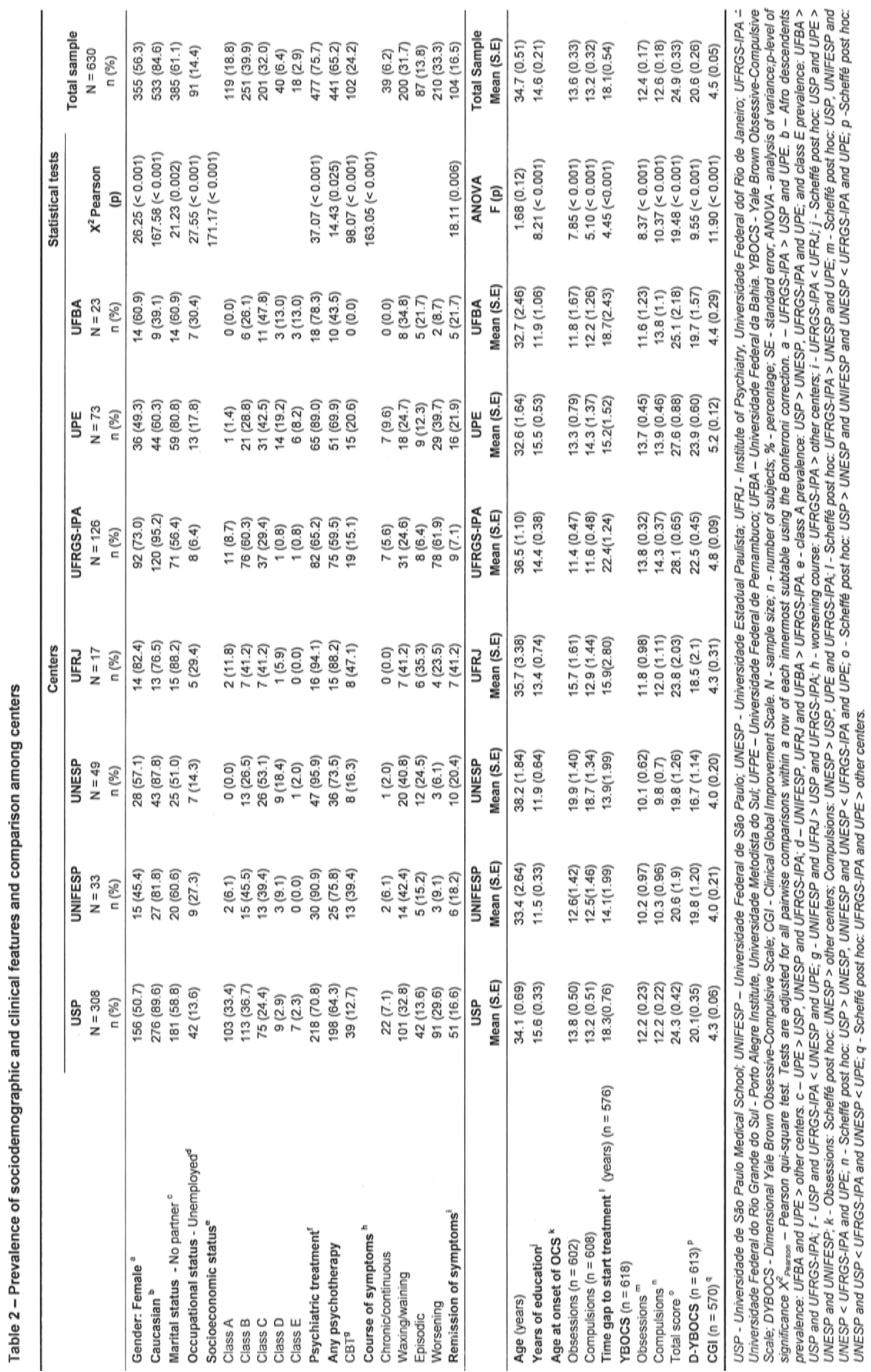




\section{2) Other studies}

Performed by some of the centers, depending on their specificities, investigating the following aspects: a) Genetic Studies (the CTOC is part of an international consortium for genetic studies in OCD). Blood serum and DNA from blood or saliva are also obtained from patients and first-degree relatives to perform molecular genetics and immunological investigations); b) Neuroimaging studies, investigating cerebral structural and functional alterations; c) Neuropsychological studies, investigating brain function as possible endophenotypes; d) Clinical trials, investigating the response to pharmacological or cognitive-behavioral approaches.

\section{Sample recruitment}

Until March 2008, a total of 630 patients had been systematically evaluated and included in the dada set.

Inclusion criteria: individuals under treatment in any of the seven sites, who had DSM-IV OCD as their main psychiatric diagnosis confirmed by the SCID-I, ${ }^{6}$ and were able to understand and agreed to participate in the research protocol.

Forty-six patients from all centers were excluded from the study: seven patients fulfilled DSM-IV diagnostic criteria for schizophrenia; one patient was unable to understand and provide informed consent and 38 subjects refused to participate: 32 due to the long time spent to answer all the research protocol, and six did not agree to sign the informed consent (two were afraid of being identified, and four did not want to supply blood for genetic research).

Sources of referral included outpatient (mostly) and inpatient clinics, clinicians in primary or secondary health care units, private psychiatric services (150 from São Paulo and 20 from Rio Grande do Sul), websites, media advertisements, self-help groups and the Brazilian Association of Obsessive-Compulsive and Tourette Syndrome Disorders (ASTOC - www.astoc.org.br). Recruitment efforts were focused on individuals living in the local area or patients presenting for treatment at the centers.

\section{Statistical analyses}

Initially, the frequency and distribution calculations of selected variables were performed for the sample as a whole, using mean \pm standard error (SE), percentages, median, minimum and maximum values. For the differences between centers, Pearson's chi-square for categorical (dichotomic or polytomic) variables was used. Tests were adjusted for all pairwise comparisons within a row of each innermost suitable using the Bonferroni correction. One-way analysis of variance (ANOVA) followed by the post-hoc Scheffé test (normal distribution) or Kruskal-Wallis $\mathrm{H}$ test (non-normal distribution) for continuous variables were performed. Scales scores (e.g. Y-BOCS, DY-BOCS, BABS, BDI, BAI, YGTSS) were analyzed as continuous variables.

The initial objective of this study was to measure the inter-rater reliability between the leaders of all CTOC centers with at least six patients thoroughly evaluated. As it is an ongoing consortium work, the reliability analyses will be continuously performed every ten cases. At this moment, for an initial reliability evaluation, only the core instruments for most studies and those that could lead to higher occurrence of disagreement between evaluators were chosen. It must be highlighted that the inter-reliability was not assessed for those scales that are very descriptive (straightforward answers)

Table 3 - Comparison between patients from public and private services of The Brazilian Research Consortium on ObsessiveCompulsive Spectrum Disorders (CTOC) initial sample $(\mathrm{N}=630)$

\begin{tabular}{|c|c|c|c|c|}
\hline & $\begin{array}{c}\text { Public }(\mathrm{N}=460) \\
n(\%)\end{array}$ & $\begin{array}{c}\text { Private }(\mathrm{N}=170) \\
\mathrm{n}(\%)\end{array}$ & Statistical test & $p$ \\
\hline Gender - Female & $285(62.0)$ & $70(41.2)$ & $X^{2}$ Yates $=21.23$ & $<0.001$ \\
\hline Ethnicity - Caucasian & $379(82.4)$ & $153(90.0)$ & $X^{2}{ }_{\text {Yates }}=6.60$ & 0.158 \\
\hline Marital status - No partner & $281(61.1)$ & $104(61.2)$ & $X^{2}$ Yates $<0.01$ & 0.992 \\
\hline Occupational status - Unemployed & $209(45.4)$ & $72(42.4)$ & $X^{2}$ Yates $=0.17$ & 0.684 \\
\hline Socioeconomic status & & & $X_{\text {Pearson }}^{2}=60.3$ & $<0.001$ \\
\hline Class A & $57(12.4)$ & $62(36.5)$ & & \\
\hline Class B & $182(39.6)$ & $71(41.7)$ & & \\
\hline Class C & $169(36.7)$ & $31(18.2)$ & & \\
\hline Class D & $37(8.0)$ & $3(1.8)$ & & \\
\hline Class E & $15(3.3)$ & $3(1.8)$ & & \\
\hline Psychiatric treatment & $351(76.3)$ & $125(73.5)$ & $X_{\text {Yates }}^{2}=0.43$ & 0.510 \\
\hline Any psychotherapy & $291(63.3)$ & $119(70.0)$ & $X^{2}$ Yates $=2.01$ & 0.156 \\
\hline Cognitive behavior therapy & $72(15.7)$ & $30(17.7)$ & $X^{2}$ Yates $=9.57$ & 0.089 \\
\hline \multirow[t]{2}{*}{ Remission of symptoms } & $72(15.7)$ & $32(18.8)$ & $X^{2}$ Yates $=0.67$ & 0.412 \\
\hline & $\begin{array}{c}\text { Public } \\
\text { mean (SE) }\end{array}$ & $\begin{array}{c}\text { Private } \\
\text { mean (SE) }\end{array}$ & Statistical test & $\mathbf{p}$ \\
\hline Age (years) & $35.3(0.60)$ & $32.9(0.95)$ & $t=-2.05$ & 0.041 \\
\hline Years of education & $14.1(0.24)$ & $16.0(0.43)$ & $t=4.20$ & $<0.001$ \\
\hline Age at onset of obsessive-compulsive symptoms (years) & $12.6(0.33)$ & $13.7(0.78)$ & $t=1.33$ & 0.185 \\
\hline Age of diagnosis (years) & $31.3(0.60)$ & $29.4(0.92)$ & $t=-1.72$ & 0.087 \\
\hline Time gap to start treatment (years) & $18.8(0.64)$ & $15.9(0.94)$ & $t=-2.52$ & 0.012 \\
\hline \multicolumn{5}{|l|}{ Y-BOCS } \\
\hline Obsessions & $12.5(0.20)$ & $12.1(0.32)$ & $t=-1.00$ & 0.32 \\
\hline Compulsions & $12.9(0.21)$ & $11.8(0.33)$ & $t=-2.80$ & 0.005 \\
\hline Total score & $21.0(0.29)$ & $19.6(0.51)$ & $t=-2.44$ & 0.015 \\
\hline DY-BOCS & $25.4(0.39)$ & $23.7(0.59)$ & $t=-2.33$ & 0.020 \\
\hline
\end{tabular}

N: sample size; $n$ : number of subjects; \% - percentage; $X^{2}{ }_{\text {yotes: }}$ Yates chi-square; $t$ - Student's t test; $p$ : level of significance; SE: standard error, Y-BOCS: Yale-Brown Obsessive-Compulsive Scale; DY-BOCS: Dimensional Yale-Brown Obsessive-Compulsive Scale 
and less clinical, with little room for disagreement. Furthermore, all participants watched the videos together and discussed each of the differences.

The statistical level of significance adopted was $5 \%$. The software used in all analyses was the Statistical Package for Social Science (SPSS), version 15.0 (SPSS Inc., Chicago, USA).

\section{Results}

\section{Inter-rater reliability}

Concerning the reliability of instrument administration between raters, the leaders of each center watched and independently rated at least six patients' videotaped interviews of the SCID-I, DY-BOCS and USP-SPS, totalizing 191 items, which were analyzed. The answers could be dichotomic or ordinal. Of these 191 items, 184 (96\%) were concordant by the eight leaders of the research centers. Three items $(1.6 \%)$ were discordant for one rater, three items (1.6\%) for two raters and one item $(0.5 \%)$ for four raters.

\section{Demographic and clinical data}

Of the 630 patients, 308 (49.0\%) came from USP, 126 (20.0\%) from Universidade Federal do Rio Grande do Sul-Universidade Metodista do Sul (UFRGS-IPA), 73 (11.6\%) from Universidade de Pernambuco (UPE), 49 (7.8\%) from Universidade Estadual Paulista (Unesp), 33 (5.2\%) from Universidade Federal de São Paulo (Unifesp), 23 (3.7\%) from Universidade Federal da Bahia (UFBA), and $17(2.7 \%)$ from Universidade Federal do Rio de Janeiro (UFRJ). Table 2 shows the main sociodemographic and clinical features for the total sample and of each of the centers. Having no partner was more frequent at the UPE center and the lowest rates of unemployment appeared at the UFRGS-IPA center. The sample evinces a higher prevalence of social class A at the USP center (reflecting the higher frequency of private patients in this center) and social class $E$ at UFBA. Higher mean educational level was found at USP (also secondary to the higher frequency of private patients in this center). The age at onset of OCS was higher for the Unesp center, and the longest time gap to start any kind of appropriate treatment occurred at UFRGS-IPA. According to Y-BOCS, DY-BOCS and $\mathrm{CGI}$, the most severe cases were presented by the UFRGS-IPA and UPE centers.

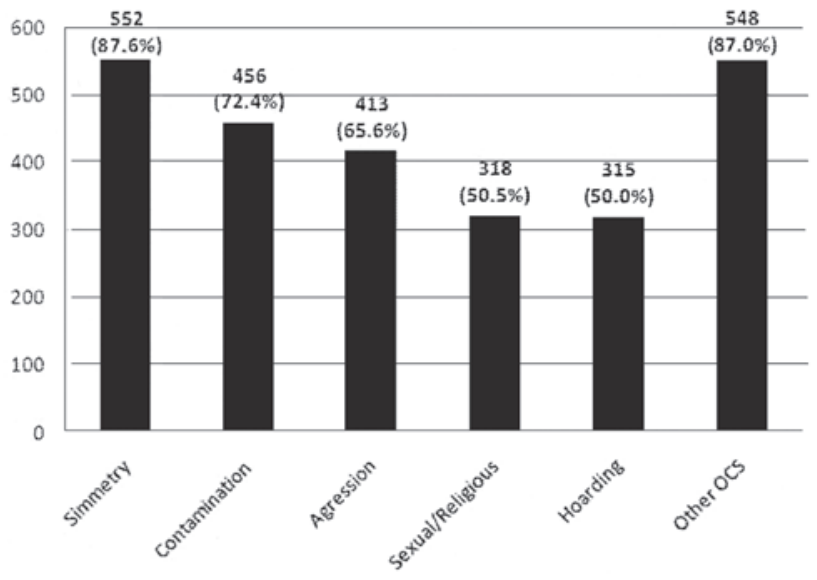

Figure 2 - Prevalence of obsessive-compulsive symptoms dimensions according to the Dimensional Yale-Brown Obsessive-Compulsive Scale (DY-BOCS)
Although it was not an initial purpose of this study, the sociodemographic and clinical characteristics of patients from private and public services were compared, since it was believed to be a potential confounding variable. The patients recruited from public services, when compared to private ones, were more likely to be female, from lower social class, less educated, and to present a longer time gap to start treatment. They also tended to be older when they get the OCD diagnosis and to have more severe OCS (measured by the Y-BOCS and DY-BOCS), as shown in Table 3.

Prior to the interview, the most frequently used anti-obsessive medications were fluoxetine ( $n=290,46.0 \%$ ); clomipramine ( $n=220,34.9 \%)$; paroxetine ( $n=166,26.3 \%)$, and sertraline ( $n=166,26.3 \%)$. The most frequently used benzodiazepines were clonazepam ( $n=185,29.4 \%$ ), diazepam ( $n=81,12.9 \%$ ), and alprazolam ( $\mathrm{n}=70,11.1 \%$ ), and the most frequently used antipsychotics associated with the SSRIs were risperidone ( $n=61,9.7 \%)$, haloperidol ( $n=52,8.3 \%)$, and olanzapine ( $n=33,5.2 \%$ ).

According to the DY-BOCS, the most prevalent symptom dimension was symmetry. The other dimensions are described in Figure 2. The most common "other OCS" were obsessions of separation from parents or other relatives ( $n=248 ; 39.4 \%$ ), superstitious obsessions ( $n=226 ; 35.9 \%$ ), obsessions about medical diseases ( $n=203 ; 32.2 \%$ ), "slowness, repetitive behaviors" ( $n=202$; $32.1 \%$ ), and compulsions to prevent from losing a relative ( $n=201 ; 31.9 \%$ ). The DY-BOCS dimensions median scores were ( $25^{\text {th }}$ percentile- $75^{\text {th }}$ percentile): aggression -4 (0-9); sexualreligious - 0 (0-8); symmetry, order - 8 (3-11); contamination, cleaning - 7 (0-11); hoarding - 0 (0-6); other OCS - 8 (3-11) and total score - 22 (18-25).

The lifetime psychiatric comorbidities are listed in Table 4. The five most common comorbidities were major depressive disorder, generalized anxiety disorder, social anxiety disorder ("social anxiety disorder" has been proposed as an alternative for the DSM-IV established term "social phobia"), simple phobia and separation anxiety (investigated in all sample, including adults). Among impulsive control disorders, skin picking appeared as the most common comorbidity followed by compulsive buying, intermittent explosive disorder and trichotillomania. Eating disorders were present in less than $10 \%$ of the sample, as well as drug/alcohol abuse or dependence and ADHD.

The mean $( \pm S E)$ age of the first tic was $12.87( \pm 0.62)$, ranging from 1 to 55 years old (median $=12.0$ ). The USP-SPS was administered to 605 subjects; 395 (65.3\%) of them presented any of the sensory phenomena and the total mean ( \pm SE) score of the scale was $7.81( \pm 0.17)$, ranging from 1 to 15 .

The mean $( \pm$ SE) score of $\mathrm{BDI}$ of 613 patients was 15.54 $( \pm 0.45)$, ranging from 0 to 53 (median $=14$ ); and of BAl was $15.15( \pm 0.46)$, ranging from 0 to 53 (median $=13.0$ ). Among the 593 patients that answered the BABS, the mean ( \pm SE) score was $6.49( \pm 0.22)$, ranging from 0 to 24 (median $=6$ ).

The quality of life of 378 patients of the sample $(60.0 \%)$, according to the SF-36, showed the following scores [mean $( \pm$ SE)]: functional capacity: $83.79( \pm 1.04)$; limitation due to physical aspects: $75.19( \pm 1.71)$; pain: $71.79( \pm 1.37)$; general health status: 64.00 ( \pm 1.27$)$; vitality: 52.84 ( \pm 1.18$)$; social aspects: 49.93 ( \pm 1.51$)$; limitation due to emotional aspects: 53.00 ( \pm 1.88$)$; mental health: $53.98( \pm 1.11)$. A total SF-36 score could be obtained through the arithmetic mean of the eight dimensions: $63.14( \pm 0.96)$. According to the EAS scores, the mean $( \pm$ SE) total score was $1.40( \pm 0.042)$ for those patients 
who work $(n=234) ; 1.73( \pm 0.041)$ for those who are housewives $(n=211)$; and $0.99( \pm 0.045)$ for those who are students $(n=95)$.

\section{Discussion}

There is considerable agreement on the need to recruit a high number of participants for clinical research on psychiatric disorders in general and OCD in particular. Large sample sizes enhance the study power to test specific hypotheses. We present the first CTOC investigating characteristics of OCD patients and their families spanning over all areas of OCD research. The main objective of the CTOC is to conduct multicenter research on OCD, using properly and uniformly administered assessment instruments in order to form a unique dataset to be used by all Consortium sites. These requirements entail a great deal of planning, mainly to standardize the training and methods, and to constantly guarantee cross-site reliability. Considering the remarkable heterogeneity of OCD, this approach optimizes the findings on specific clinical phenotypes of the disorder, which is extremely relevant for clinical, genetic, neuropsychological, neuroimaging and treatment outcome studies.

So far, our research assessment protocol has proved to be successful. The interviews exhibited adequate inter-rater reliability, an essential step for a multicenter initiative like this. The continuing regular meetings have allowed CTOC members to "test" the applicability of the assessment package and to identify current or potential problems. This strategy also favored the clarification of

Table 4 - Axis I lifetime psychiatric comorbidities of the sample

\begin{tabular}{|c|c|c|}
\hline Axis I psychiatric comorbidity & $\mathbf{n}$ & $\%$ \\
\hline \multicolumn{3}{|l|}{ Affective disorders } \\
\hline Major depressive disorder & 439 & 69.7 \\
\hline Dysthymic disorder & 67 & 10.6 \\
\hline Bipolar I disorder & 28 & 4.4 \\
\hline Bipolar II disorder & 35 & 5.6 \\
\hline \multicolumn{3}{|l|}{ Anxiety disorders } \\
\hline Generalized anxiety disorder & 223 & 35.4 \\
\hline Social phobia & 232 & 36.8 \\
\hline Specific anxiety disorder & 204 & 32.4 \\
\hline Post-traumatic stress disorder & 98 & 15.6 \\
\hline Panic + Agoraphobia & 54 & 8.6 \\
\hline Agoraphobia & 36 & 5.7 \\
\hline Panic disorder & 39 & 6.2 \\
\hline \multicolumn{3}{|l|}{ Eating disorders } \\
\hline Periodic alimentary compulsion & 51 & 8.1 \\
\hline Anorexia & 18 & 2.9 \\
\hline Bulimia & 17 & 2.7 \\
\hline \multicolumn{3}{|l|}{ Substance dependence } \\
\hline Alcohol & 47 & 7.5 \\
\hline Other drugs & 15 & 2.4 \\
\hline \multicolumn{3}{|l|}{ Impulse control disorders } \\
\hline Skin picking & 105 & 16.7 \\
\hline Compulsive buying & 68 & 10.8 \\
\hline Intermittent explosive disorder & 53 & 8.4 \\
\hline Trichotillomania & 36 & 5.7 \\
\hline Compulsive sexual behavior & 20 & 3,2 \\
\hline Compulsive "interneting" & 19 & 3.0 \\
\hline Kleptomania & 16 & 2.5 \\
\hline Pathological gambling & 5 & 0.8 \\
\hline \multicolumn{3}{|l|}{ Other disorders } \\
\hline Tic disorder & 181 & 28.7 \\
\hline Tourette's disorder & 44 & 7.0 \\
\hline Separation anxiety disorder ${ }^{*}$ & 155 & 24.6 \\
\hline Somatization disorder & 22 & 3.5 \\
\hline Body dysmorphic disorder & 73 & 11.6 \\
\hline Attention-deficit/hyperactivity disorder* & 54 & 8.6 \\
\hline Delusional disorder & 2 & 0.3 \\
\hline
\end{tabular}

$n$ - number of subjects; \% - percentage of subjects. * Investigated in all sample (including adults) several clinical questions and the immediate correction of some quandaries, including unclear decision trees or imprecise statements. Nevertheless, the current absence of appropriate validation of the instruments in Brazil may, to some extent, limit some findings of our studies. As it is an ongoing research Consortium, future papers will acknowledge this core methodological aspect.

After the first two years of active recruitment, 630 participants (much more than the predefined goal) have been successfully evaluated and their data inserted in the core data bank. Some caution on the external validity of all studies derived from this sample should be taken. All CTOC centers are specialized university services or private clinics for OCD treatment, probably comprising more severe cases. Therefore, the results cannot be directly generalized to OCD patients from primary or secondary health care units, neither to community samples.

It is also uncertain to what extent the results can be generalized to other countries and cultures, despite the similar profile of the main OCD clinical features worldwide. ${ }^{21}$ In Brazil, only two community-based studies (restricted to big urban areas) have been conducted. The lifetime prevalence rates of OCD found in the general population were $0.7 \%$ in Brasilia-DF, $2.1 \%$ in Porto Alegre-RS ${ }^{22}$ and $0.3 \%$ in São Paulo-SP. ${ }^{23}$ Most surveys conducted in other countries and cultures have found lifetime prevalence ranging from $0.3 \%$ to $3.0 \% .{ }^{24}$ Although these quite distinct estimates may reflect methodological differences among sites, such as different interviewers' training and skills, they are more likely due to some regional differences in a country with so much cultural variety. ${ }^{24,25}$

Nevertheless, the CTOC sample includes patients from different Brazilian states and regions and the patients' demographic and clinical characteristics differ in many aspects between the centers, as indicated by the initial comparative analysis reported here. Otherwise the sample ethnic distribution resembles the Brazilian cultural heterogeneity (Brazilian Institute of Geography and Statistics, 2008-IBGE, available at http//:www.ibge.org.br), since the centers from the Northeast region, in contrast with the centers from the South, present lower frequency of Caucasian participants.

This CTOC sample also includes patients from private and public services. The longer time gap to start treatment in the public services, when compared to the private ones, may indicate deficiencies in the current public health system in the identification and management of OCD cases. Considering the level of education, as measured by the number of years of formal education, the twoyear difference found between these groups, although statistically significant, does not seem to be clinically relevant. It is worthwhile to stress that even the participants from public services had a much higher level of education compared to the Brazilian general population, which ranges from 4.6 years in the Northeast to 6.6 years in the Southeast region (Brazilian Institute of Geography and Statistics, 2008-IBGE, available at http//:www.ibge.org.br). Therefore, a possible difference on the capacity to understand the assessment instruments by individuals from private and public services is very unlikely. Furthermore, participants with considerable difficulties in understanding the research questions were excluded from the study.

Although the YBOCS and D-YBOCS showed statistically significant differences between public and private participants, one point in the YBOCS compulsions subscale and 1.4 points in the D-YBOCS total score do not seem to evince clinical relevance.

This is the first study with a large sample to evaluate OCS using a dimensional questionnaire (DY-BOCS). The results are 
similar to other two previously published papers with 48 and 137 patients, ${ }^{2,10}$ which indicated the dimension of symmetry, order and arrangement as the most prevalent one. Another instrument evaluating subjective experiences of physical or mental sensations associated with repetitive behaviors (sensory phenomena) - the USP-SPS - was also widely used for the first time. The prevalence of sensory phenomena in this sample $(65.3 \%)$ was similar to that of other studies, where they ranged from $40 \%$ to $57.5 \% .^{1,15,26-28}$ The mean score on $\mathrm{BDI}$ and $\mathrm{BAI}$ were consonant with other international studies, ${ }^{29}$ but lower than one previous Brazilian study. ${ }^{30}$ The BABS mean score was similar to that found by Phillips et al. in 198 OCD patients: $6.8( \pm 4.9) .^{31}$

Our findings concerning comorbid axis I conditions are generally in the reported ranges for OCD clinical samples, which were differently ascertained and vary considerably. As in most studies, major depressive disorder was the most frequent comorbid condition, followed by anxiety disorders in general. In the literature, the rates for depressive episodes vary from 20-67\%, for specific phobias from $7 \%-22 \%$, for social anxiety disorder from $8-42 \%$ and generalized anxiety disorder from 8-32\%.32-38 The slightly higher figures for some disorders in our sample may be due to the fact that these patients are from specialized or tertiary services, which usually assist more severe cases. The $7.5 \%$ prevalence of alcohol dependence is similar to that of other clinical studies ${ }^{34,39}$ and much lower than that of community studies, ${ }^{40,41}$ as expected.

There are differences regarding the types of comorbid psychiatric disorders found in community and clinical samples, probably because of their impact on help-seeking behaviors. ${ }^{42}$ The CTOC sample presents a comorbidity pattern that is similar to what is expected in clinical studies. Lifetime prevalence of mood, anxiety and tic disorders are very similar to findings from previous studies with OCD patients who are under treatment. ${ }^{26,43}$ On the other hand, this study presents original findings regarding the prevalence of specific impulse control disorders that had never been systematically investigated in such a large sample. The relatively high frequency of comorbidity with skin picking and the relatively low frequency of compulsive sexual behavior, compulsive "interneting," kleptomania and pathological gambling found in this sample may serve as an additional evidence suggesting that skin picking may be part of the obsessive-compulsive spectrum disorders ${ }^{44}$ as opposed to a more "impulsive spectrum," which would include the other putative impulse control disorders. ${ }^{45,46}$ More studies in this area of OCSD are clearly needed. Addictive behaviors, such as those involved in drug and alcohol abuse and dependence are much less frequent in clinical samples, compared to general population samples, indicating that some OCD sufferers may be using substances to deal with their symptoms instead of seeking treatment. ${ }^{37}$

The results regarding some aspects of the patient's quality of life (QoL) (i.e., vitality, social, emotional and mental health) reflect the negative impact of OCD severity and other co-occurring symptoms (i.e., depressive, anxious). The importance of studying this aspect is that QoL may be an appropriate indicator of treatment impact on several aspects of the patient's life. ${ }^{47}$ Severe OCD symptoms may lead to the same levels of QoL and family burden of schizophrenic patients, especially on psychological and social domains. ${ }^{48}$ Even with relatively mild mean scores of depression and anxiety symptoms, their additional impact on OCD may increase the patient's burden and, probably, of their families. ${ }^{25}$ More specific analyses of QoL of these patients will be described in future papers, regarding clinical aspects that can have different impact, such as obsessions or compulsions, as suggested by Stengler-Wenzke et al. ${ }^{49}$

The CTOC participants are confident that their main goals have been successfully achieved so far. Relevant clinical data have been systematically and uniformly collected, a large database for collaborative studies has been built, graduate and post-graduate students are receiving research training in this field, and expert groups are under continuous development throughout the country. This effort will certainly generate new findings that can contribute to the understanding and treatment of OCSD, which hopefully will lead to a better standard of care for Brazilian patients and their families and may serve as a model to be followed in other countries.

In conclusion, the CTOC has established an important network for recruitment and implemented methods for standardized assessment of OCD patients in Brazil. In addition, the chosen instruments also allowed, for the first time, a comprehensive evaluation and measurement of multiple intrinsic and extrinsic OCD features in a large clinical sample. It was possible, for the first time in our country, to draw a general demographic and clinical profile of OCD patients from different regions: most of them are Caucasian, unmarried, with some kind of occupational activity, mean age of 35 years and onset of OCS at 13 years of age, symptoms of mild to moderate severity, higher prevalence of symmetry and contamination/cleaning symptoms and comorbidity with depression. The present findings provide a strong methodological backbone for the studies to come. Moreover, the CTOC may pave the way to similar projects aimed at integrating other Brazilian research groups. 


\section{Disclosures}

\begin{tabular}{|c|c|c|c|c|c|c|c|}
\hline Writting group member & Employment & $\begin{array}{l}\text { Research } \\
\text { grant }^{1}\end{array}$ & $\begin{array}{c}\text { Other research grant or } \\
\text { medical continuous } \\
\text { education }{ }^{2}\end{array}$ & $\begin{array}{l}\text { Spekear's } \\
\text { honoraria }\end{array}$ & $\begin{array}{c}\text { Ownership } \\
\text { interest }\end{array}$ & $\begin{array}{l}\text { Consultant/ } \\
\text { Advisory } \\
\text { board }\end{array}$ & Other ${ }^{3}$ \\
\hline Euripedes C. Miguel & IPq-HC-FMUSP & $\begin{array}{l}\text { FAPESP } \\
\text { CNPq }\end{array}$ & Novartis & - & - & $\begin{array}{l}\text { CNPq } \\
\text { FAPESP } \\
\text { CAPES }\end{array}$ & - \\
\hline Ygor Arzeno Ferrão & $\begin{array}{c}\text { Universidade } \\
\text { Metodista do Sul }\end{array}$ & - & - & $\begin{array}{c}\text { Ely Lilly } \\
\text { Bōeringher } \\
\text { Novartis } \\
\text { Roche } \\
\text { Solvay Pharma }\end{array}$ & - & - & -- \\
\hline $\begin{array}{l}\text { Maria Conceição do } \\
\text { Rosário }\end{array}$ & $\begin{array}{l}\text { UNIFESP } \\
\text { UFBA }\end{array}$ & -- & - & - & - & - & Novartis \\
\hline Maria Alice de Mathis & IPq-HC-FMUSP & FAPESP & - & - & - & - & - \\
\hline Albina Rodrigues Torres & UNESP & - & - & - & - & - & - \\
\hline $\begin{array}{l}\text { Leonardo Franklin } \\
\text { Fontenelle }\end{array}$ & $\begin{array}{l}\text { UFRJ }^{\star} \\
\text { UFF* }^{\star}\end{array}$ & $\begin{array}{l}\text { CNPq }{ }^{\star \star \star *} \\
\text { FAPERJ }\end{array}$ & - & - & - & - & $\begin{array}{c}\text { Lundbeck* } \\
\text { Servier* } \\
\text { Abbott* } \\
\text { Guanabara- } \\
\text { Koogan* }\end{array}$ \\
\hline Ana Gabriela Hounie & IPq-HC-FMUSP & CAPES & - & - & - & - & - \\
\hline Roseli Gedanke Shavitt & IPq-HC-FMUSP & FAPESP & - & - & - & - & - \\
\hline $\begin{array}{l}\text { Aristides Volpato } \\
\text { Cordioli }\end{array}$ & HCPA & - & - & $\begin{array}{l}\text { Speeches and } \\
\text { courses }^{\star}\end{array}$ & - & - & Copyright* \\
\hline Cristina Hojaij Gonzalez & UNIFESP & - & - & - & - & - & - \\
\hline Kátia Petribú & UPE & - & - & - & - & - & $\begin{array}{l}\text { Astra- } \\
\text { Zêneca }\end{array}$ \\
\hline Juliana Belo Diniz & IPq-HC-FMUSP & $\begin{array}{l}\text { FAPESP***} \\
\text { CNPq }\end{array}$ & Novartis & - & - & - & Jansen-Cilag \\
\hline Dante Marino Malavazzi & IPq-HC-FMUSP & PIBIC & - & - & - & - & - \\
\hline Ricardo C. Torresan & UNESP & - & - & - & - & - & - \\
\hline Andréa Litvin Raffin & HCPA & CAPES & - & - & - & - & - \\
\hline Elisabeth Meyer & HCPA & $\mathrm{CNPq}$ & - & - & - & - & - \\
\hline Daniela T. Braga & HCPA & - & - & - & - & - & - \\
\hline Sonia Borcato & IPq-HC-FMUSP & - & - & - & - & - & - \\
\hline Carolina Valério & IPq-HC-FMUSP & - & - & - & - & - & - \\
\hline Luciana N. Gropo & UPE & FAPESP & - & - & - & - & - \\
\hline Helena da Silva Prado & UNIFESP & CAPES & - & - & - & - & - \\
\hline Eduardo Alliende Perin & UNIFESP & - & - & - & - & - & - \\
\hline Sandro lêgo Santos & UFBA & - & - & - & - & - & - \\
\hline Helen Copque & UFBA & - & - & - & - & - & - \\
\hline Manuela Corrêa Borges & UFRJ & - & - & - & - & - & - \\
\hline Angélica Prazeres Lopes & UFRJ & - & - & - & - & - & - \\
\hline Elenita D. da Silva & UPE & - & - & - & - & - & - \\
\hline
\end{tabular}

\section{*Modest}

* Significant

** Significant. Amounts given to the author's institution or to a colleague for research in which the author has participation, not directly to the author.

Note: IPq-HC-FMUSP = Departamento e Instituto de Psiquiatria do Hospital das Clinicas da Faculdade de Medicina da Universidade de São Paulo; UNIFESP = Universidade Federal de São Paulo; UFRJ = Universidade Federal do Rio de Janeiro; UFF = Universidade Federal Fluminense; UFBA = Universidade Federal da Bahia; UPE = Universidade de Pernambuco; UNESP = Universidade Estadual Paulista; HCPA = Hospital de Clínicas de Porto Alegre; FAPESP = Fundação de Amparo à Pesquisa do Estado de São Paulo; CNPq = Conselho Nacional de Desenvolvimento Científico e Tecnológico; FAPERJ = Carlos Chagas Filho de Amparo à Pesquisa do Estado do Rio de Janeiro; CAPES = Coordenação de Aperfeiçoamento de Pessoal de Nivel Superior, PIBIC = Programa Institucional de Bolsas de Iniciação Cientifica.

For more information, see Instructions for authors.

References

1. Miguel EC, Coffey BJ, Baer L, Savage CR, Rauch SL, Jenike MA. Phenomenology of intentional repetitive behaviors in obsessive-compulsive disorder and Tourette's disorder. J Clin Psych. 1995;56(6):246-55.

2. Ferrão YA, Shavitt RG, Bedin NR, de Mathis ME, Lopes AC, Fontenelle LF, Torres AR, Miguel EC. Clinical features associated to refractory obsessivecompulsive disorder. J Affect Disord. 2006;94(1-3):199-209.

3. Ferrão YA, Diniz JB, Lopes AC, Shavitt RG, Greenberg B, Miguel EC. Resistance and refractoriness in obsessive-compulsive disorder. Rev Bras Psiquiatr. 2007;29(Supl II):S66-76.

4. Calkins ME, Dobie DJ, Cadenhead KS, Olincy A, Freedman R, Green MF, Greenwood TA, Gur RE, Gur RC, Light GA, Mintz J, Nuechterlein KH, Radant AD, Schork NJ, Seidman LJ, Siever LJ, Silverman JM, Stone WS, Swerdlow NR, Tsuang DW, Tsuang MT, Turetsky BI, Braff DL. The Consortium on the Genetics of Endophenotypes in Schizophrenia: model recruitment, assessment, and endophenotyping methods for a multisite collaboration. Schizophr Bull. 2007;33(1):33-48.
5. Johnston-Wilson NL, Sims CD, Hofmann JP, Anderson L, Shore AD, Torrey EF, Yolken RH. Disease-specific alterations in frontal cortex brain proteins in schizophrenia, bipolar disorder, and major depressive disorder. The Stanley Neuropathology Consortium. Mol Psychiatry. 2000;5(2): 142-9.

6. First MB, Spitzer RL, Gibbon M, Williams JB. Structured clinical interview for DSM-IV axis I disorders: clinical version (SCID-CV). Washington, DC: American Psychiatric Press, 1997.

7. First MB. Structural clinical interview for DSM-IV-TR Impulse Control Disorders Not Elsewhere Classified (SCID-TCIm). Biometrics Research Department; New York State Psychiatric Institute; 2004.

8. Kaufman J, Birmaher B, Brent D, Rao U, Flynn C, Moreci P, Williamson D, Ryan N. Schedule for Affective Disorders and Schizophrenia for SchoolAged Children - Present and Lifetime (K-SADS-PL): initial reliability and validity data. J Am Acad Child Adolesc Psych. 1997;36(7):980-8.

9. Goodman WK, Price LH, Rasmussen SA, Mazure C, Fleischmann RL, Hill CL, Heninger GR, Charney DS. The Yale-Brown Obsessive 
Compulsive Scale. I. Development, use, and reliability. Arch Gen Psychiatry. 1989;46(11):1006-11.

10. Rosario-Campos MC, Miguel EC, Quatrano S, Chacon P, Ferrao Y, Findley D, Katsovich L, Scahill L, King RA, Woody SR, Tolin D, Hollander E, Kano Y, Leckman JF. The Dimensional Yale-Brown Obsessive-Compulsive Scale (DY-BOCS): an instrument for assessing obsessive-compulsive symptom dimensions. Mol Psychiatry. 2006;11(5):495-504.

11. Leckman JF, Riddle MA, Hardin MT, Ort SI, Swartz KL, Stevenson J, Cohen DJ.. The Yale Global Tic Severity Scale: initial testing of a clinician-rated scale of tic severity. J Am Ac Child Adoles Psych. 1989;28(4):566-73.

12. Beck AT, Ward CH, Mendelson M, Mock J, Erbaugh J. An inventory for measuring depression. Arch Gen Psychiatry. 1961;4:561-71.

13. Beck AT, Epstein N, Brown G, Steer RA. An inventory for measuring clinical anxiety: psychometric properties. J Consult Clin Psychol. 1988;56(6):893-7.

14. Gorenstein C, Andrade L. Validation of a Portuguese version of the Beck Depression Inventory and the State-Trait Anxiety Inventory in Brazilian subjects. Braz J Med Biol Res. 1996;29(4):453-7.

15. Miguel EC, do Rosário-Campos MC, Prado HS, do Valle R, Rauch SL, Coffey BJ, Baer L, Savage CR, O'Sullivan RL, Jenike MA, Leckman JF Sensory phenomena in patients with obsessive-compulsive disorder and/or Gilles De La Tourette Syndrome. J Clin Psychatry. 2000;61(2):150-6.

16. Mattos P, Serra-Pinheiro MA, Rohde LA, Pinto D. Apresentação de uma versão em português para uso no Brasil do instrumento MTASNAP-IV de avaliação de sintomas de transtorno do déficit de atenção/ hiperatividade e sintomas de transtorno desafiador e de oposição. Rev Psiquiatr Rio Gd Sul. 2006;28(3):290-7.

17. Eisen JL, Phillips KA, Baer L, Beer DA, Atala KD, Rasmussen SA. The Brown Assessment of Beliefs Scale: reliability and validity. Am J Psychiatr. 1998;155(1):102-8.

18. Gorenstein C, Moreno RA, Bernik MA, Carvalho SC, Nicastri S, Cordás T, Camargo AP, Artes R, Andrade L. Validation of the Portuguese version of the social adjustment scale in Brazilian samples. J Affect Disord. 2002;69(1-3):167-75.

19. Ciconelli RM, Ferraz MB, Santos W, Meinão I, Quaresma MR. Tradução para a língua portuguesa e validação do questionário genérico de avaliação de qualidade de vida SF-36 (Brasil SF36) / Brazilian-Portuguese version of the SF-36. A reliable and valid quality of life outcome measure. Rev Bras Reumatol. 1999;39(3):143-50.

20. Guy W. Clinical global impression (CGI). In: ECDEU Assessment Manual for Psychopharmacology. US Department of Health and Human Services, Public Health Service, Alcohol Drug Abuse and Mental Health Administration, NIMH psychopharmacology Research branch. Rockville: National Institute of Mental Health; 1976.

21. Fontenelle LF, Mendlowicz MV, Marques C, Versiani M. Trans-cultural aspects of obsessive-compulsive disorder: a description of a Brazilian sample and a systematic review of international clinical studies. J Psychiatr Res. 2004;38(4):403-11.

22. Almeida Filho N, Mari JJ, Coutinho E, França JF, Fernandes JF, e cols. Estudo multicêntrico de morbidade psiquiátrica em áreas urbanas brasileiras (Brasília, São Paulo, Porto Alegre). Rev ABP-APAL. 1992;14(3):93-104

23. Andrade L, Walters EE, Gentil V, Laurenti R. Prevalence of ICD-10 mental disorders in a catchment area in the city of São Paulo, Brasil. Soc Psychiatry Psychiatr Epidemiol. 2002;37(7):316-25.

24. Torres AR, Lima MC. Epidemiology of obsessive-compulsive disorder: a review. Rev Bras Psiquiatr. 2005;27(3):237-42.

25. Niederauer KG, Braga DT, Souza FP, Meyer E, Cordioli AV. Quality of life in individuals with obsessive-compulsive disorder: a review. Rev Bras Psiquiatr. 2007;29(3): 271-8.

26. Diniz JB, Rosario-Campos MC, Hounie AG, Curi M, Shavitt RG, Lopes AC, Miguel EC. Chronic tics and Tourette syndrome in patients with obsessive-compulsive disorder. J Psychiatr Res. 2006;40(6):487-93.

27. Shavitt RG, Belotto C, Curi M, Hounie AG, Rosario-Campos MC, Diniz JB, Ferrão YA, Pato MT, Miguel EC. Clinical features associated with treatment response in obsessive-compulsive disorder. Compr Psychiatry. 2006; 47(4):276-81.

28. Nakata AC, Diniz JB, Torres AR, de Mathis MA, Fossaluza V, Bragança CA, Ferrão Y, Miguel EC. Level of insight and clinical features of obsessive-compulsive disorder with and without body dysmorphic disorder. CNS Spectr. 2007;12(4):295-303.

29. Cottraux J, Note I, Yao SN, Lafont S, Note B, Mollard E, Bouvard M, Sauteraud A, Bourgeois M, Dartigues JF. A randomized controlled trial of cognitive therapy versus intensive behavior therapy in obsessive compulsive disorder. Psychother Psychosom. 2001;70(6):288-97.

30. Sousa MB, Isolan LR, Oliveira RR, Manfro GG, Cordioli AV. A randomized clinical trial on cognitive-behavioral group therapy and sertraline in the treatment of obsessive-compulsive disorder. J Clin Psych. 2006;67(7):1133-9.

31. Phillips KA, Pinto A, Menard W, Eisen JL, Mancebo M, Rasmussen SA. Obsessive-compulsive disorder versus body dysmorphic disorder: a comparison study of two possibly related disorders. Depress Anxiety. 2007:24(6):399-409.

32. Attiullah N, Eisen JL, Rasmussen SA. Clinical features of obsessivecompulsive disorder. Psychiatr Clin North Am. 2000;23(3):469-91.

33. Steketee G, Chambless DL, Tran GQ. Effects of axis I and II comorbidity on behavior therapy outcome for obsessive-compulsive disorder and agoraphobia. Compr Psychiatry. 2001;42(1):76-86

34. Tükel R, Polat A, Ozdemir O, Aksüt D, Türksoy N. Comorbid conditions in obsessive-compulsive disorder. Compr Psychiatry. 2002:43(3):204-9.

35. Rasmussen SA, Eisen JL. The epidemiology and differential diagnosis of obsessive compulsive disorder. J Clin Psychiatry. 1994;55(Suppl 5-10):discussion 11-4.

36. Crino RD, Andrews G. Obsessive-compulsive disorder and axis I comorbidity. J Anxiety Dis. 1996;10(1):37-46

37. Milanfranchi A, Marazziti D, Pfanner C, Presta S, Lensi P, Ravagli S, Cassano GB. Comorbidity in obsessive-compulsive disorder: Focus on depression. Eur Psychiatry. 1995;10(8): 379-82.

38. Sobin C, Blundell M, Weiller F, Gavigan C, Haiman C, Karayiorgou M. Phenotypic characteristics of Obsessive-Compulsive Disorder ascertained in adulthood. J Psych Res. 1999;33(3):265-73.

39. Yaryura-Tobias JA, Grunes MS, Todaro J, McKay D, Neziroglu FA, Stockman R. Nosological insertion of axis I disorders in the etiology of obsessive-compulsive disorder. J Anxiety Dis. 2000;14(1):19-30.

40. Karno M; Golding JM, Sorenson SB, Burnam MA. The epidemiology of obsessive-compulsive disorder in five US communities. Arch Gen Psychaitry. 1988;45(12):1094-9.

41. Torres AR, Prince MJ, Bebbington PE, Bhugra D, Brugha TS, Farrel M, Jenkins R, Lewis G, Meltzer H, Singleton N.. Obsessive-compulsive disorder: prevalence, comorbidity, impact and help-seeking in the British National Psychiatric Morbidity Survey of 2000. Am J Psych. 2006;163(11):1978-85

42. Torres AR, Prince MJ, Bebbington PE, Bhugra DK, Brugha TS, Farrell $M$, Jenkins R, Lewis $G$, Meltzer $H$, Singleton N. Treatment seeking by individuals with obsessive-compulsive disorder from the British psychiatric morbidity survey of 2000. Psychiatr Serv. 2007;58(7):977-82

43. Tükel R, Polat A, Ozdemir O, Aksüt D, Türksoy N. Comorbid conditions in obsessive-compulsive disorder. Compr Psychiatry. 2002;43(3):204-9.

44. Bienvenu OJ, Samuels JF, Riddle MA, Hoehn-Saric R, Liang KY, Cullen BA, Grados MA, Nestadt G. The relationship of obsessive-compulsive disorder to possible spectrum disorders: results from a family study. Biol Psychiatry. 2000;48(4):287-93.

45. Dell'Osso B, Altamura AC, Allen A, Marazziti D, Hollander E. Epidemiologic and clinical updates on impulse control disorders: a critical review. Eur Arch Psychiatry Clin Neurosci. 2006;256(8):464-75.

46. Ferrão Y, Miguel EC, Stein D. Tourette's disorder, trichotillomania, and obsessive-compulsive disorder: how closely are they related? Psych Res. 2008 (accepted).

47. Norberg MM, Calamari JE, Cohen RJ, Riemann BC. Quality of life in obsessive-compulsive disorder: an evaluation of impairment and a preliminary analysis of the ameliorating effects of treatment. Depress Anxiety. 2008;25(3):248-59.

48. Gururaj GP, Math SB, Reddy J, Chandrashekar CR. Family burden, quality of life and disability in obsessive compulsive disorder: An Indian perspective. J Postgrad Med. 2008;54(2):91-7.

49. Stengler-Wenzke K, Kroll M, Riedel-Heller S, Matschinger $\mathrm{H}$, Angermeyer MC. Quality of life in obsessive-compulsive disorder: the different impact of obsessions and compulsions. Psychopathology. 2007;40(5):282-9. 